\title{
Non-Self-Executing Treaties and the Suspension Clause After St. Cyr
}

Ogbudimkpa v. Ashcroft, 342 F.3d 207 (3d Cir. 2003).

In INS v. St. Cyr, ${ }^{1}$ the Supreme Court rejected Congress's attempt to foreclose judicial review in various provisions of the Antiterrorism and Effective Death Penalty Act (AEDPA) of $1996^{2}$ and the Illegal Immigration Reform and Immigrant Responsibility Act (IIRIRA) of 1996. ${ }^{3}$ The St. Cyr Court held that Congress must be extraordinarily explicit whenever it intends for legislation to strip courts of the jurisdiction to hear any class of habeas petitions, including the deportation-related claims that AEDPA and IIRIRA sought to restrict. ${ }^{4}$ Such a "superclear" concluded, was needed to avoid the potential constitutional problem posed by the Suspension Clause, which bars foreclosure of habeas "unless when in Cases of Rebellion or Invasion the public Safety may require it."

Habeas has traditionally been available to allege violations of not only the Constitution and statutory law, but also of ratified treaties that are "selfexecuting" and statutes implementing ${ }^{8}$ ratified treaties that are not. ${ }^{9}$ On

1. 533 U.S. 289 (2001).

2. Pub. L. No. 104-132, 110 Stat. 1214 (codified as amended in scattered sections of 8,15 , $18,21,22,28,40,42,49$, and 50 U.S.C.).

3. Pub. L. No. 104-208, div. C, 110 Stat. 3009-546 (codified as amended in scattered sections of $8,18,20,22,28,32,42,48$, and 50 U.S.C.).

4. St. Cyr, 533 U.S. at 299. St. Cyr's holding, at least on this jurisdictional point, was affirmed and expanded upon last Term in Demore v. Kim, 123 S. Ct. 1708 (2003).

5. St. Cyr, 533 U.S. at 327 (Scalia, J., dissenting).

6. U.S. CONST. art. I, $\S 9$, cl. 2.

7. The Supreme Court has defined a "self-executing" treaty as one for which "no domestic legislation is required to give [it] the force of law in the United States." Trans World Airlines, Inc. v. Franklin Mint Corp., 466 U.S. 243, 252 (1984). Under the Restatement view, a ratified treaty is "self-executing" so long as it is not "non-self-executing," and treaties are non-self-executing "(a) if the agreement manifests an intention that it shall not become effective as domestic law without the enactment of implementing legislation, (b) if the Senate in giving consent to a treaty, or Congress by resolution, requires implementing legislation, or (c) if implementing legislation is constitutionally required." RESTATEMENT (THIRD) OF THE FOREIGN RELATIONS LAW OF THE UNITED STATES $\S 111(4)$ (1987); see also id. $\S 111 \mathrm{cmt}$. h ("If the [treaty] is silent as to its selfexecuting character ..., account must be taken of any statement by the President in concluding the agreement or in submitting it to the Senate for consent or to the Congress as a whole for approval, and of any expression by the Senate or by Congress in dealing with the agreement."). 
August 22, 2003, the Third Circuit, in Ogbudimkpa v. Ashcroft, ${ }^{10}$ became the fourth circuit court (following the First, Second, and Ninth Circuits ${ }^{11}$ ) to consider whether the jurisdiction-stripping provisions of the Foreign Affairs Reform and Restructuring Act (FARRA) of $1998^{12}$ sufficed to bar habeas petitions alleging violations of the U.N. Convention Against Torture (CAT). ${ }^{13}$ FARRA implemented the United States's treaty obligations under the non-self-executing CAT, and the Ogbudimkpa court, like the others before it, found FARRA's language materially similar to that which the St. Cyr Court had held to be insufficiently clear to foreclose habeas.

At first glance, Ogbudimkpa appears to be a straightforward result compelled by St. Cyr. But in applying St. Cyr to another habeas-stripping statute, the Third Circuit paid an unusual amount of attention to the interaction between habeas and non-self-executing treaties themselves, considered apart from any implementing legislation. In the past several years, no fewer than seven circuits have held that habeas is not available to enforce rights conferred only by non-self-executing treaties. ${ }^{14}$ This Comment argues, however, that after St. Cyr, courts are on far shakier ground in barring the use of habeas to litigate claims under non-selfexecuting treaties, and that Ogbudimkpa, though not directly on point, suggests why.

The argument begins with an overview of FARRA and St. Cyr's superclear statement rule, and the extension of the latter to the former in Ogbudimkpa. Part II focuses on an intriguing footnote in Ogbudimkpa that suggests one statutory explanation for why other circuits that have considered the relationship between habeas petitions and non-self-executing treaties absent implementing legislation may have thus far gotten it wrong. Part III moves on to the constitutional question implicitly suggested by the

8. A non-self-executing treaty can be "implemented" if a statute is enacted that writes the United States's treaty obligations into federal law. A self-executing treaty needs no such legislation. See Flores v. S. Peru Copper Corp., 343 F.3d 140, 163 n.34 (2d Cir. 2003).

9. For the fountainhead decision on the availability of habeas to enforce treaty violations, see Wildenhus's Case, 120 U.S. 1 (1887).

10. 342 F.3d 207 (3d Cir. 2003).

11. See Saint Fort v. Ashcroft, 329 F.3d 191 (1st Cir. 2003); Wang v. Ashcroft, 320 F.3d 130 (2d Cir. 2003); Cornejo-Barreto v. Seifert, 218 F.3d 1004 (9th Cir. 2000); see also Singh v. Ashcroft, 351 F.3d 435 (9th Cir. 2003); Zachary Margulis-Ohnuma, Note, Saying What the Law Is: Judicial Review of Criminal Aliens' Claims Under the Convention Against Torture, 33 N.Y.U. J. INT'L L. \& POL. 861 (2001).

12. 8 U.S.C. $\$ 1231$ note $(2000)$.

13. Convention Against Torture and Other Cruel, Inhuman or Degrading Treatment or Punishment, Dec. 10, 1984, S. TREATY DOC. NO. 100-20 (1988), 1465 U.N.T.S. 85.

14. See Bannerman v. Snyder, 325 F.3d 722 (6th Cir. 2003); Wang, 320 F.3d 130; Hamdi v. Rumsfeld, 316 F.3d 450 (4th Cir. 2003), cert. granted, 124 S. Ct. 981 (2004) (No. 03-6696); Wesson v. U.S. Penitentiary, 305 F.3d 343 (5th Cir. 2002), cert. denied, 537 U.S. 1241 (2003); Hain v. Gibson, 287 F.3d 1224 (10th Cir. 2002), cert. denied, 537 U.S. 1173 (2003); United States ex rel. Perez v. Warden, FMC Rochester, 286 F.3d 1059 (8th Cir.), cert. denied, 537 U.S. 869 (2002); Garza v. Lappin, 253 F.3d 918 (7th Cir. 2001). 
Third Circuit: Because a superclear statement of legislative intent to foreclose habeas is required when Congress enacts statutory law, then shouldn't the Supremacy Clause require the same in the treaty context, whether the treaty is self-executing or not? Part IV concludes.

In 1998, Congress enacted FARRA, section 2242(a) of which implemented the United States's nonrefoulment obligations under Article 3 of CAT.$^{15}$ In section 2242(d), Congress attempted to restrict judicial review of CAT claims, mandating that "nothing in this section shall be construed as providing any court jurisdiction to consider or review claims raised under the Convention or this section ... except as part of the review of a final order of removal." 16

Three years later, the St. Cyr Court found analogous language in AEDPA and IIRIRA insufficient to foreclose the availability of habeas corpus. ${ }^{17}$ Distinguishing between "judicial review" in general and habeas specifically, ${ }^{18}$ Justice Stevens, writing for the majority, found that reading AEDPA and IIRIRA to foreclose habeas would raise serious constitutional questions under the Suspension Clause. ${ }^{19}$ Invoking the constitutional avoidance canon, the Court concluded that "[ $t]$ he necessity of resolving such a serious and difficult constitutional issue - and the desirability of avoiding that necessity-simply reinforce the reasons for requiring a clear and unambiguous statement of congressional intent." 20 Except where congressional intent to foreclose habeas was absolutely manifest (and the constitutional question thus squarely unavoidable), habeas would lie.

On the heels of St. Cyr, the Third Circuit's decision in Ogbudimkpa was unsurprising. Christopher Ogbudimkpa, a Nigerian citizen, was ordered deported in 1996, but he successfully reopened his removal proceedings in

15. See Foreign Affairs Reform and Restructuring Act (FARRA) of 1998, Pub. L. No. 105-227, § 2242(a), 112 Stat. 2681-761, 2681-822 (codified at 8 U.S.C. $\$ 1231$ note). Under Article 3, "[n]o State Party shall expel, return (refouler) or extradite a person to another State where there are substantial grounds for believing that he would be in danger of being subjected to torture." Convention Against Torture and Other Cruel, Inhuman or Degrading Treatment or Punishment, supra note 13, art. 3, S. TREATY DOC. NO. 100-20, at 20, 1465 U.N.T.S. at 114.

16. FARRA \& 2242(d).

17. INS v. St. Cyr, 533 U.S. 289, 308-14 (2001). In St. Cyr, the government argued that four provisions of AEDPA and IIRIRA restricted habeas. Three purported to limit "judicial review," see id. at 310-14, and the fourth, though titled "Elimination of Custody Review by Habeas Corpus," only repealed a technical provision of the Immigration and Nationality Act, see id. at 308-10. Because none spoke directly in their text to the elimination of habeas, as opposed to judicial review generally, the Court found them insufficiently clear to strip jurisdiction. Id. at 314 .

18. Id. at 311-13.

19. Id. at 304 .

20. Id. at 305; see also Gerald L. Neuman, The Habeas Corpus Suspension Clause After INS v. St. Cyr, 33 COLUM. HUM. RTS. L. REv. 555 (2002) (surveying the constitutional concerns). 
1999 on the ground that he credibly feared torture if he was removed to Nigeria. After a complicated procedural back-and-forth between the Middle District of Pennsylvania and the Third Circuit, the district court eventually dismissed his habeas petition for want of subject matter jurisdiction, finding habeas foreclosed by FARRA. ${ }^{21}$

A unanimous Third Circuit panel reversed, holding, as the First and Second Circuits had before it, ${ }^{22}$ that section 2242(d) of FARRA was in no material way different from the statutory provisions at issue in St. Cyr:

With strong indication from the Supreme Court that nothing will suffice but the most explicit statement that habeas jurisdiction under 28 U.S.C. $\S 2241$ is repealed, and because $\S 2242(\mathrm{~d})$ of FARRA does not mention habeas corpus or 28 U.S.C. $\$ 2241$, we conclude, by analogy to St. Cyr, that FARRA does not foreclose a district court from exercising habeas jurisdiction over claims alleging violations of CAT. ${ }^{23}$

The government's argument in Ogbudimkpa centered on CAT's status as a non-self-executing treaty. St. Cyr, it claimed, was inapposite because no habeas jurisdiction had existed under CAT in the first place: FARRA's restrictive language had been written to limit its additional grant of habeas jurisdiction, not to strip a preexisting jurisdictional source. ${ }^{24}$ The court disagreed, concluding that "the proper starting point is the question whether FARRA deprives the District Court of habeas jurisdiction, not whether it grants it. Habeas relief is available for an individual who claims his or her continued detention violates a statute or a treaty." ${ }^{25}$ The fact that FARRA's additional grant of jurisdiction had been enacted contemporaneously with its related restrictions was immaterial to the Ogbudimkpa court; St. Cyr still controlled. $^{26}$

In refusing to adopt the government's position, the Third Circuit also moved beyond other circuits in its discussion of Ogbudimkpa's argument (itself a response to the government's claim) that habeas can be based on non-self-executing treaties that have not been implemented by statute. The

21. See Ogbudimkpa v. Ashcroft, 342 F.3d 207, 209-11 (3d Cir. 2003).

22. Saint Fort v. Ashcroft, 329 F.3d 191 (1st Cir. 2003); Wang v. Ashcroft, 320 F.3d 130 (2d Cir. 2003); see also Cornejo-Barreto v. Seifert, 218 F.3d 1004 (9th Cir. 2000) (predating St. Cyr).

23. Ogbudimkpa, 342 F.3d at 217.

24. See id. at 218 (describing the government's position).

25. See id. at $219-20$.

26. See id. at 220 ("It follows that those individuals whose detention violates FARRA may challenge their detention under 28 U.S.C. $\$ 2241$, just as with any other detentions that violate federal law. Thus, whether CAT is or is not self-executing is irrelevant." (citations and footnote omitted)); see also Saint Fort, 329 F.3d at 202; Wang, 320 F.3d at 141 n.16. 
court considered the conventional claim that such treaties cannot create any jurisdiction because non-self-executing treaties "must be implemented by legislation before [they] give[] rise to a private cause of action,",27 and because jurisdiction, in turn, must be limited to the adjudication of those private rights of action that a treaty confers.

Although the court shied away from expressing any final opinion on the question, it nonetheless seemed to reject the conventional argument, noting that "[r]atification purporting to cabin a treaty as non-self-executing nonetheless provides jurisdiction to the United States courts to hear cases premised on its violation," even though such a treaty "does not provide a cause of action." ${ }^{28}$ The private cause of action for habeas, the court argued, is guaranteed by other provisions of federal law; a treaty need only provide jurisdiction for the courts to hear such a claim. ${ }^{29}$ As the Third Circuit summarized, "[T] he general habeas statute provides a cause of action that 28 U.S.C. $\S 1331$ does not. As a result ... a treaty that is ratified but not self-executing need not be implemented in order for a party to have a habeas cause of action under that treaty." $" 30$

The court's contention - that jurisdiction created by non-self-executing treaties may be enforceable through otherwise available causes of actionis an important one, for it highlights how the other circuits that have considered the interaction between non-self-executing treaties and habeas have ignored the critical distinction between a court's jurisdiction and a litigant's cause of action. In its discussion, the Third Circuit thus uncovered a potentially serious inconsistency in the basic premise of non-selfexecuting habeas law. Contrary to the Third Circuit, most courts assume that non-self-execution is a bar to the enforcement of treaty rights in any form. Yet it is possible that the non-self-executing nature of a treaty is not fatal to an assertion of jurisdiction under it, provided that the cause of

27. Ogbudimkpa, 342 F.3d at 219 n.22 (internal quotation marks omitted). For a more detailed discussion of the jurisdiction/cause-of-action distinction, see Carlos Manuel Vázquez, Treaty-Based Rights and Remedies of Individuals, 92 CoLUM. L. REV. 1082, 1141-57 (1992). For a typical example of the summary treatment this argument has received, see Bannerman $v$. Snyder, 325 F.3d 722, 724 (6th Cir. 2003). The lack of more in-depth discussions of the special nature of habeas claims is curious, especially since the St. Cyr Court focused on precisely this distinction in explaining why the foreclosure of habeas requires a "superclear" statement of legislative intent. See INS v. St. Cyr, 533 U.S. 289, 311-13 (2001).

28. Ogbudimkpa, 342 F.3d at 219 n.22 (emphasis added).

29. See id.; see also 28 U.S.C. § 2241(c)(3) (2000) (providing that habeas is available to prisoners "in custody in violation of the Constitution or laws or treaties of the United States").

30. Ogbudimkpa, 342 F.3d at 219 n.22 (citation omitted); see also In re Extradition of Mironescu, 296 F. Supp. 2d 632, 637 (M.D.N.C. 2003) ("This is an enticingly simple formulation that does no more than take the statutes at their word .... [W]hen the President, two-thirds of the Senate, and at least one other foreign sovereign all agree to create an individual right for persons in custody, that right should be immediately cognizable under $\$ 2241$." (internal quotation marks omitted)). 
action over which jurisdiction is asserted already exists in some other statute-as is the case for habeas petitions.

\section{III}

The Third Circuit's consideration in Ogbudimkpa of the difference between jurisdiction and causes of action was focused at the statutory level. But the Ogbudimkpa court also hinted at another, more significant potential problem with barring habeas claims when a non-self-executing treaty lacks implementing legislation: the constitutional concerns raised by the Suspension Clause and highlighted by St. Cyr. The court noted that under the government's argument,

the question that the Supreme Court asked in St. Cyr-is there evidence that Congress intended to foreclose the availability of habeas review-is turned around in the context of a non-selfexecuting treaty and becomes, instead, whether there is evidence that Congress intended to provide for the availability of habeas review. ${ }^{31}$

But, as the Third Circuit concluded, the St. Cyr inquiry is the same in every context, and does not get "turned around in the context of a non-selfexecuting treaty." By implication, then, the same inquiry must be made of the ratification of a non-self-executing treaty, and not just-as in Ogbudimkpa - of the statute implementing it: "[I]s there evidence that Congress [qua the Senate] intended to foreclose the availability of habeas review" when it ratified a non-self-executing treaty?

The Ogbudimkpa court did not phrase the question this way, nor did it attempt to follow the argument to its logical conclusion, but the Suspension Clause implications, thanks to $S t$. Cyr, are manifest. In ratifying treaties, the Senate is, ipso facto, enacting federal law. ${ }^{32}$ As long as one considers nonself-executing treaties to be treaties, St. Cyr bars the Senate from stripping federal courts of habeas jurisdiction when ratifying such treaties, unless it makes a superclear statement to that effect. Otherwise, "the lack of a clear, unambiguous, and express statement of congressional intent to preclude judicial consideration on habeas of such an important question of law[] strongly counsels against adopting a construction that would raise serious

31. Ogbudimkpa, 342 F.3d at 219.

32. See In re Comm'r's Subpoenas, 325 F.3d 1287, 1305 (11th Cir. 2003) ("A treaty, when ratified, supersedes prior domestic law to the contrary, and is equivalent to an act of Congress." (internal quotation marks omitted)); see also Maiorano v. Balt. \& Ohio R.R. Co., 213 U.S. 268, $272-73$ (1909) ("A treaty, . . . by the express words of the Constitution, is the supreme law of the land, ... and must be enforced by [courts] in the litigation of private rights."). 
constitutional questions." ${ }^{, 33}$ Yet currently, only courts—not the President or the Senate-are stating that the enactment of a non-self-executing treaty serves to foreclose habeas. Under St. Cyr, this is not enough.

Such a superclear statement should be required from the President and the Senate for all non-self-executing treaties-even those already enacted. The case law foreclosing the use of habeas to enforce rights conferred by such treaties postdates nearly all of the major international agreements that purport to impose limits on executive detention-that is, nearly all of the treaties that confer rights that habeas petitions could potentially enforce. ${ }^{34}$ Suggesting that the Senate's intent to foreclose habeas is clearly manifested in ambiguous declarations about non-self-execution long before courts began holding that such a characterization was sufficient to abrogate judicial review is a stretch, at best.

To be sure, the most obvious criticism of this thesis is that non-selfexecuting treaties are not actually "treaties" per either the Supremacy Clause or the federal habeas statute. Under this claim, a non-self-executing treaty may be little more than a judicially unenforceable promise to a foreign state that the treaty will be abided by. If such a treaty is not the supreme law of the land, the constitutional limitation of the Suspension Clause would be irrelevant, since no legislative action would have occurred.

But the Supreme Court has never suggested this dichotomy - that selfexecuting treaties are the supreme law of the land, but non-self-executing treaties are not. If anything, the plain text of the Supremacy Clause, encompassing "all treaties," implies the opposite, and the Court has never hinted otherwise in discussing the relationship of treaties to that provision. Whether a treaty is self-executing or not dictates whether it gives rise to independent remedies; that a treaty is ratified by the Senate in the first place is all the Constitution requires for the Supremacy Clause to attach. ${ }^{35}$

\section{IV}

The Suspension Clause concerns that motivated the Supreme Court's decision in St. Cyr could be resolved with respect to non-self-executing treaties in one of three ways: First, the Court might formally resolve this debate in favor of the status quo among the circuits-which, as discussed

33. INS v. St. Cyr, 533 U.S. 289, 314 (2001).

34. Foremost among these treaties is the International Covenant on Civil and Political Rights, Dec. 19, 1966, S. EXEC. DOC. E, 95-2 (1978), 999 U.N.T.S. 171. Also relevant today, at least with regard to military detainees, are the Geneva Convention Relative to the Protection of Civilian Persons in Time of War, Aug. 12, 1949, 6 U.S.T. 3516, 75 U.N.T.S. 287, and the Geneva Convention Relative to the Treatment of Prisoners of War, Aug. 12, 1949, 6 U.S.T. 3316, 75 U.N.T.S. 135. For a survey, see David Sloss, The Domestication of International Human Rights: Non-Self-Executing Declarations and Human Rights Treaties, 24 YALE J. INT'L L. 129 (1999).

35. See, e.g., cases cited supra note 32. 
above, would require a holding that non-self-executing treaties are actually not "treaties" under the Supremacy Clause. ${ }^{36}$ Second, the Court could instead address the constitutional issue, and define the precise scope of the Suspension Clause vis-à-vis non-self-executing treaties (a project that the St. Cyr Court intentionally declined to attempt with regard to U.S. immigration law). Third, the Court could directly extend both the holding and the principle of St. Cyr and avoid the constitutional question by concluding that non-self-executing treaties, like statutes, actually $d o$ require superclear statements to foreclose habeas--hopefully with some idea of what such a statement would have to look like. ${ }^{37}$

Regardless of the specific approach the Court adopts, some resolution of this inconsistency is necessary, and soon. ${ }^{38}$ Among the major treaties presently considered entirely or partially non-self-executing are nearly all of the most significant covenants in international humanitarian law, including the International Covenant on Civil and Political Rights and the Geneva Conventions, among others. ${ }^{39}$ The body of international law conferring rights on U.S. detainees is almost entirely embodied within these treaties (with the notable exception of CAT), and most of their key provisions, as of this writing, have been held unenforceable via habeas precisely because they are non-self-executing. ${ }^{40}$

In light of St.Cyr, such decisions are constitutionally suspect, for they fail to consider the extent to which the foreclosure of habeas implicates the Suspension Clause. The availability of the writ to enforce rights conferred by non-self-executing treaties thus remains an open question, and one that the Supreme Court must clarify as an increasing number of courts confront habeas petitions alleging treaty violations.

—Stephen I. Vladeck

36. Indeed, one of the typical arguments for why specific treaties should be non-selfexecuting is fear over the extent to which the treaty may impinge on the constitutional authority of the House of Representatives. See, e.g., RESTATEMENT (THIRD) OF THE FOREIGN RELATIONS LAW OF THE UNITED STATES, supra note $7, \S 111 \mathrm{cmt}$. i \& reporter's note 5 . But this concern has no force in the habeas context, since the only issue is the lawfulness of a detainee's confinement.

37. This Comment does not mean to suggest that every provision of every treaty ratified by the United States would thus be enforceable via habeas. But in the case of non-self-executing provisions that conflict with federal or state law (for example, the ICCPR and the death penalty), this Comment's argument implies that courts will have to reach and resolve the complicated question of whether the treaty or the domestic law should control, and why. To date, courts have ducked this thomy issue by invoking the contention that habeas is unavailable for non-selfexecuting treaties. Because of St. Cyr, such summary avoidance can no longer hold.

38. One variation on the themes of this Comment has also been raised-albeit in passing-in one of the amicus briefs in Hamdi v. Rumsfeld. See Brief of Amici Curiae Former Prisoners of War and Experts on the Law of War in Support of Petitioners at 8-10, Hamdi v. Rumsfeld, $124 \mathrm{~S}$. Ct. 981 (2004) (No. 03-6696) (on file with author).

39. See sources cited supra note 34.

40. But see United States v. Lindh, 212 F. Supp. 2d 541, 553-54 (E.D. Va. 2002) (suggesting that numerous provisions of the Geneva Conventions are self-executing); United States $v$. Noriega, 808 F. Supp. 791, 797-99 (S.D. Fla. 1992) (same). 